\title{
SEVEN TOOLS AS THE PROBLEM SOLVING WAYS TO IMPROVE QUALITY CONTROL
}

\author{
Rachmasari Pramita Wardhani ${ }^{1}$, Erwin Gustianta ${ }^{2}$ \\ Program Studi Teknik Mesin, Fakultas Teknik, Universitas Tridharma ${ }^{1}$, PDAM Balikpapan ${ }^{2}$ \\ Email : rrrachmasari@gmail.com ${ }^{1}$, rwing.ir@gmail.com ${ }^{2}$
}

\begin{abstract}
ABSTRAK
Ada banyak cara bagi perusahaan untuk mencapai standar yang baik untuk barang dan jasanya. Standar penting untuk mencapai tingkat kepercayaan pelanggan. Perusahaan harus menjaga kualitas jasa dan produknya, termasuk dalam hal ini kualitas barang disamping jasa. Untuk memastikan pencapaiannya, diperlukan sistem dan proses manajemen yang terarah untuk mencapai tingkat kepercayaan pelanggan.

Banyak perusahaan menggunakan alat berkualitas untuk membantu memantau dan mengelola sistem kualitas mereka. Ada beberapa jenis alat yang bisa digunakan. Namun lebih, ada tujuh alat manajemen untuk pengendalian kualitas yang paling umum. Tujuh alat dapat digunakan oleh profesional mana pun untuk memudahkan proses peningkatan kualitas seperti diagram alir, lembar periksa, diagram Pareto, diagram sebab dan akibat, histogram, diagram pencar, dan diagram kendali.
\end{abstract}

Kata Kunci : tujuh alat , pengendalian , kualitas, problem solving

\begin{abstract}
There are many ways for the company to reach a good standard for their goods and services. Standard is essential to achieve a level of customer trust. The company must be maintaining the quality of their services and products, including in this case the quality of goods beside the services. To ensure its achievement, a directed management system and processes are needed to achieve the level of customer trust.

Many companies use quality tools to help monitor and manage their quality system. There are several types of tools that can be used. But the more, there are seven management tools for quality control are the most common. Seven tools can be used by any professional to ease the quality improvement process like flowcharts, check sheets, Pareto diagrams, cause and effect diagrams, histograms, scatter diagrams, and control charts.
\end{abstract}

Key words : seven tools, control, quality, problem solving

\section{PREFACE}

There are many ways for the company to reach a good standard for their goods and services. Standard is essential to achieve a level of customer trust. The company must be maintaining the quality of their services and products, including in this case the quality of 
goods beside the services. To ensure its achievement, a directed management system and processes are needed to achieve the level of customer trust. Many companies use quality tools to help monitor and manage their quality system. There are several types of tools that can be used. But the more, there are seven management tools for quality control are the most common. Seven tools can be used by any professional to ease the quality improvement process like flowcharts, check sheets, Pareto diagrams, cause and effect diagrams, histograms, scatter diagrams, and control charts. The concept behind the seven basic tools came from Kaoru Ishikawa, is a renowned quality expert from Japan. Dr. Ishikawa (1915 - 1989) had a profound impact on quality improvement worldwide. Dr. Ishikawa developed the concept of quality circles. He believed that everyone should be involved in quality improvement. Quality circles provided a method of doing this in the organizations. It enabled everyone to work on process improvement by suggesting ideas to improve products and processes. Quality control is a part of quality management system, it is an important factor for company or organization to become lean and more productive. In order to check quality first is identify the attribute that want to measure.

The author has chosen in the writing of this scientific paper, it is about "Seven tools as the problem solving ways to improve quality control ". The topic before ever published by Neyestani, B. (2017). Seven Basic Tools of Quality Control: The Appropriate Techniques for Solving Quality Problems.

\section{METHOD}

In this writing, the method used by the author is descriptive research method and narrative analysis. according to Webster and Metrova (2007), narrative ( narrative ) is a research method in the social sciences. The essence of this method is its ability to understand a person's identity and world view by referring to the stories (narratives) that he listens to or tells in his daily activities. Thus narrative research can be interpreted as the study of a story that tells and describes an event that is the center of attention of researchers based on a specific time sequence in detail.

According to Polikinghome (1988) in Sandelowski (1991), narrative research is categorized into two, namely descriptive and explanatory . In descriptive category narrative research, the researcher tries to describe (a) part or all of individual and group experiences, (b) the relationship between one storyline and another, (c) the benefits of an event for human life. While in category narrative research explanatory , the researcher is trying to make a story about how something happened.

\section{ANALYSIS}

\section{Basics quality tools}

Many types of controlling tools has been used in several of companies. But the old seven tools for quality control that are very common as a different tool is used for different problemsolving techniques. in the top of management system level must be familiar and know well about these problem solving tools to implementing in the company. these tools are namely;

1) Cause and Effect Diagrams,

2) Flow Charts,

3) Check sheets,

4) Histograms,

5) Pareto Charts,

6) Control Charts or Shewhart Chart,

7) Scatter Diagrams.

\section{Cause and effect diagrams}

The cause and effect diagram also known as the 'fishbone diagram' or Ishikawa diagram , the diagram looks like a fish Skelton. The Father in 'Quality Circles' Professor K. Ishikawa, was the first to develop the Cause and Effect Analysis in the 1960s.

Brainstorming is done, and then a diagram is developed after all of the possible causes of a problem. In this way, a thorough analysis is done of any specifics of the situation. This method is best when dealing with complicated issues.

The most commonly used in categoare in diagram case are people, machine, method, measurement, material, and environment. 


\section{Cause and Effect Diagram}

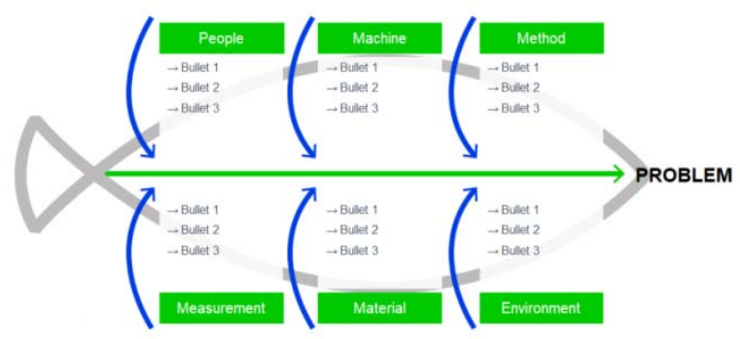

Figure 1 Cause and effect diagram

Source: ease.io

\section{Flow chart}

A flow chart is a diagram that shows the step-by-step flow of operation to get a solution of a problem or to figure out the correct sequence of the process. Flow charts are often used to document existing process standards, so they become guidelines in carrying out the production process. Flow charts or flow diagrams are also used to carry out analysis of the production process so that they can make continuous improvements to the process. Flow chart is a tool used to perform Process Planning, Process Analysis and Process Documentation as standard Production Guidelines. The following are standard shapes or symbols that are often found in Flow charts:
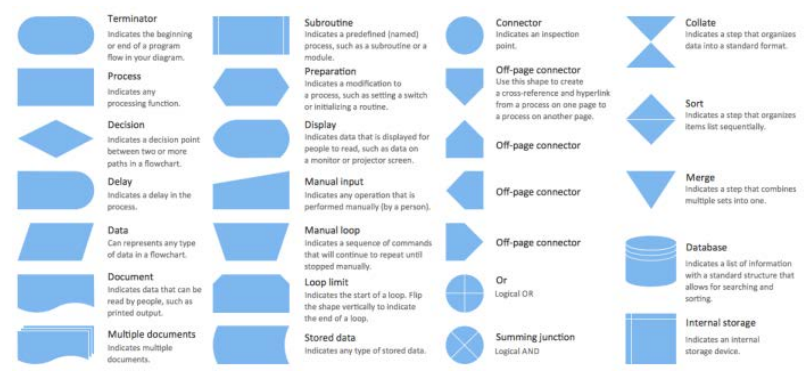

Figure 2 flow chart symbol Source : conceptdraw.com

\section{Check sheets,}

The check sheet is one of the simplest of basic quality tools. Here, use it to collect data. IT is used for collecting and analyzing data in real time at the location where the data is generated. Data Collection is staring point of useful process improvement and problem-solving tools. A checksheet is also called a tally sheet.
According to Ishikawa (1982), check sheets have the following functions:

- Production process distribution checks,

- Defective item checks,

- Defective location checks,

- Examination of the causes of defects (defective cause checks),

- Check-up confirmation checks

\section{Histograms,}

A histogram is the most commonly used graph to show frequency distributions. A histogram is a graph of the frequency distribution in which the vertical axis represents the count (frequency) and the horizontal axis represents the possible range of the data values. It displays the different measures of central tendency (mean, mode, and average). It should be designed properly for those working into the operation process can easily utilize and understand them. Also, a histogram can be applied to investigate and identify the underlying distribution of the variable being explored (Omachonu and Ross, 2004; Forbes and Ahmed, 2011).

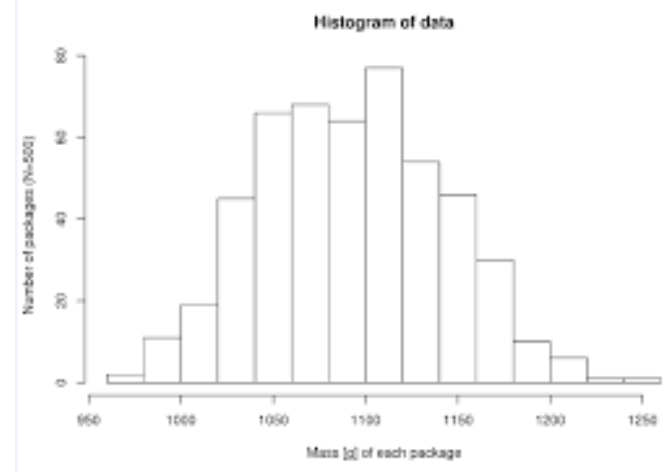

Figure 3 histogram

Histograms can show what the normal distribution is for a process that is running smoothly. However, by routinely producing histograms, any variation is quickly detected. This is a major advantage for organizations because it supports finding and dealing with process variation quickly. In Six Sigma, it is used to find variation in a process. A bar chart is used to show, for example, where delays are occurring by finding the frequency of delays in each step of the process. Using the data, project 
leaders can then find the best ways to reduce variation.

\section{Pareto Charts,}

Pareto analysis uses the pareto principle, also called the 80:20 rule, to analyze and display data. Quality expert J.M Juran applied the principle to quality control. And found that 80 percent of problems stem from 20 percent of the possible causes. The numbers 80 and 20 are not meant to be absolutes. The main point as Juran stated is that we should focus on the vital few problems (those in 20 percent category) rather than on the trival many to make the most significant improvements in product quality.

A pareto chart are a graphical tool used in Pareto analysis, it is a bar chart that displays the relative importance of problems in a format that is very easy to interpret. Some of the problems for examples are like measurement, frequency, etc. is represented by the tallest bar, the next most important problem is represented by the next tallest bar and so on. When you look at a Pareto Chart, you can see break points in the heights of the bars which indicate the most important categories. This information is useful when you are establishing priorities.

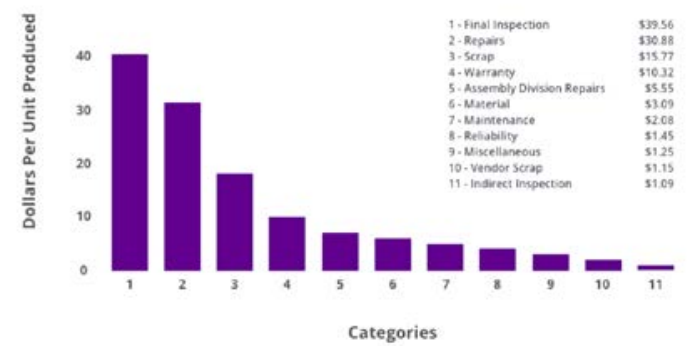

Figure 4 Diagram Pareto

Source : Juran.com

6. Control Charts or Shewhart Chart,

Walter Shewhart in 1924 designed a chart to indicate whether or not the observed variations in the percent of defective apparatus of a given type are significant; that is, to indicate whether or not the product is satisfactory". This was the first control chart, and it has been the basis of statistical quality control ever since. The data obtained regularly from the QC materials are, in general,evaluated by control charts.
A control chart (also known as a Shewhart chart) is a graph used to study how a system or process changes over time. Data is plotted in time order. Control chart always has a mean as the centre line, an upper control limit and a lower control limit which show where we would expect future data.

The centre line, upper control limit and lower control limit help us when interpreting the variation that exists in the process. By comparing current data to these lines, it can identify whether the process is stable and predictable (common cause variation) or unstable and needs investigation (special cause variation). A control chart we can know how monitor process performance, prediction the process performance in the future, find out the improvement and monitor sustainability of improvements.

\section{Out of Control}

Beyond Control Limit Indicates Lack of Control for Process. Control charts can show problems with processes when a identifiable cause exists in the system. A process with a identifiable cause is said to be "out of control". Some of the data points for the control chart will be outside the control limits. In other words, if any measurement or test data is outside the control limits, it will be known that something is wrong in the process. Obviously, this is the time to take corrective action.

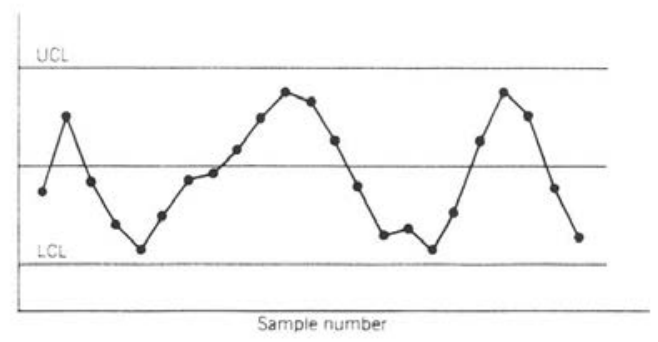

Figure 5 Control Chart

\section{Scatter Diagrams.}

A scatter diagram - also known as a "scatter plot" - is a graphic representation of the relationship between two variables. Teams use scatter diagrams to help them identify causeand-effect relationships between two variables. For example, after brainstorming multiple causes and effects using a fishbone (cause and effect) 
diagram, your team might use a scatter diagram to determine whether a particular cause and effect are related.

A scatter diagram graphs one variable on the $\mathrm{X}$-axis and the other variable on the $\mathrm{Y}$ axis. If the two variables are related, the data points will fall along a diagonal line or curve that is, values for variable $\mathrm{X}$ will be associated with values for variable $Y$. This could show either a positive correlation (values for both variables increase or decrease) or a negative correlation (values for one variable increase while those for the other decrease).
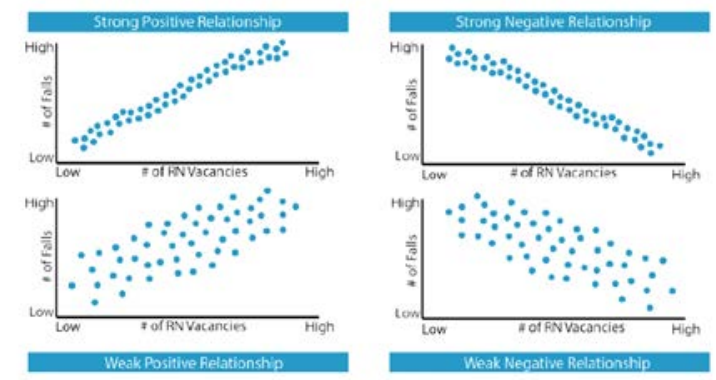

Figure 6 Scatter Diagram

\section{CONCLUSION}

Seven tools method are carried out as quality control aims to improve the quality of processes and products so it can be can be more effective and more efficient, to reach customers satisfaction with good quality and increase profits for the company. The seven tools will help the company or organization to solve their problems as the way of solution.

1. We use cause and effect or fishbone diagram to see and analyze the cause of the matter problems. This can help you search for root causes, identify areas where there may be problems, and compare the relative importance of different causes.

2. With the help of flowchart, problem can be analysed in more effective way therefore reducing cost and wastage of time. The diagrams themselves can improve communication of processes and workflows, especially when an existing process is being updated or refined. For instance, manufacturing employees can follow a flowchart while setting up machines.
3. Using a check sheet is appropriate when the data can be observed and collected repeatedly by either the same person or the same location. Cheek sheet is an effective tool when collecting data on frequency and identifying patterns of events, problems, defects, and defect location, and for identifying defect causes.

4. Histogram is show the shape and distribution of your data. The greatest benefit that comes with their use is the ability to monitor basic information about the dataset, such as the median value, the width of spread and the overall distribution.

5. Pareto diagram analysis can help improve the efficiency, profitability, and effectiveness of company performance. which can optimize the performance of the organization as a whole.

6. A Control Chart also helps in checking the process stability and verifying whether the process is stable enough to improve and make necessary improvements in the process wherever required.

7. The purposes of using a Scatter Diagram, which is to show the correlation exists between two sets of data.

\section{REFERENCE}

Manfred Reichenba“cher l Ju"rgen W. Einax ,Challenges in Analytical Quality Assurance,springer, 2011. Chapter 8

Piotr Konieczka and Jacek Namie'snik “Quality Assurance and Quality Control in the Analytical Chemical Laboratory: A Practical Approach, Taylor \& Francis Group, 20009. Chapter 1.9

W. Funk, V. Dammann, G. Donnevert, Quality Assurance in Analytical Chemistry: Applications in Environmental, Food, and Materials Analysis, Biotechnology, and Medical Engineering", John Wily, 2007. Chapter 2.6.7

Montgomery, D. C. (1990). Pengantar Pengendalian Kualitas dan Statistik. 
Gajah Mada University Press, Yogyakarta.

Heizer, J., \& Render, B. (2011). Operation Management (10th edition). Upper Saddle River, N.J : Prentice Hall

Besterfield, D. H. (2003). Total quality management (3rd edition). New York: Pearson Education Inc.

Neyestani. B, (2017), Seven Basic Tools of Quality Control: The Appropriate Techniques for Solving Quality Problems in the Organizations. https://doi.org/10.5281/zenodo.40083

2 